\title{
Narratives of Epidemics: Topsy-turvy Conditions of Humans and Quest for Existence
}

\author{
Abdel-Fattah M. Adel ${ }^{1}$, Mashhoor Abdu Al-Moghales ${ }^{2}$ \& Suhail Ahmad ${ }^{3}$ \\ ${ }^{1}$ Department of English, College of Arts, University of Bisha, Saudi Arabia. \\ Email: aadeal@ub.edu.sa, ORCID: oooo-ooo1-7968-8167 \\ ${ }^{2}$ Department of English, College of Arts, University of Bisha, Saudi Arabia and Taiz \\ University, Yemen. Email: mamohammad@ub.edu.sa, ORCID: oooo-ooo1-7984-5388 \\ ${ }^{3}$ Department of English, College of Arts, University of Bisha, Saudi Arabia. \\ Email: suhailahmed@ub.edu.sa, ORCID: oooo-ooo1-6611-2484
}

\begin{abstract}
Corpus of literature is replete with works that feature pandemics as central themes. As a response to diseases outbreaks, fiction writers portray the human condition and the shifts in human behaviour at these crucial junctures of human history. Plot structure and characterization accounts for the void -both within and without-: prevailing chaos, crumbling social structures, undermining of religious values, and Government's apathy. Based on such themes, this paper examines, from Deterministic and Existentialistic perspectives, three representative fictions written in the $21^{\text {st }}$ century: Reina James's This Time of Dying (2006) on the deadly influenza of 1918, Amir Taj Elsir's Ebola '76 (2012) on the outbreak of Ebola in 1976, and Karen Maitland's The Plague Charmer (2016) on the plague of 1361. The findings include: (a) the novels predict the contemporary society with their resonance of apocalyptic images and preventive measures, (b) they manifest ontological shifts as the orthodox worldviews are jolted, and (c) fictional and personal narratives are not less important than historical records on health in quest for existence.
\end{abstract}

Keywords: Epidemic Novels, Human Conditions, Determinism, Freewill.

\section{Introduction}

Pandemics have been a recurrent theme in literature. Human conditions intertwined with shifts in human behaviour as the plague strikes have been fundamental in defining the plot and characterization of such fictions. Above all, they bring a threat to human existence. Even if there are some differences in the human reactions to a plague, still, they all "share a terrible fear, the fear of death-both as the end of one's life and as the end of civilization" (Riva et al., 2014, p. 1755). Such deeply rooted fears result in deep modifications in human behaviour, norms and values. This aspect of the human experience is conspicuous by its absence in historical and medical narratives. Literature is the best repository of these individual narratives on the level of the individual and the community. Fiction can recount the human experience vividly since "these descriptions tell us more about the plague and its social implications than do the several accounts by physicians" because they carry "the flavor of reality" (Keys, 1944, pp. 35-37). They are not texts "written about" the plague; rather, it is a plague "written into them" (Cooke, 2009, p. 16).

The craving for pandemics as a theme in literature have been alluring, i.e. "there is an order of attraction where illness is concerned" (Steel, 1981, p. 88). Boccaccio's The Decameron

(C) AesthetixMS 2020. This Open Access article is published under a Creative Commons Attribution Non-Commercial 4.o International License (http://creativecommons.org/licenses/by-nc/4.o/), which permits non-commercial re-use, distribution, and reproduction in any medium, provided the original work is properly cited. For citation use the DOI. For commercial re-use, please contact editor@rupkatha.com. 
(1353) presents pictorial tropes of Black Death in the $14^{\text {th }}$ century: parents refused to nurse "their own children" (p. 54). Chaucer's The Pardoner's Tale (c. 1400) portrays the moral degeneration of the post-plague age as "the morality of those who survived worsened" (Beidler, 1982, p. 258). Thomas Dekker in The Wonderfull Yeare (1603) gives the image of plague of 1603 as a cruel tyrant in literature which "gave plague a distinct moral place in popular thought" (Newman, 2012, p. 811). Great Plague of London of 1665 finds most sustained account in Dafoe's A Journal of the Plague Year (1722). Whereas, the central argument in Albert Camus's novel The Plague (1947) about the pandemics occurring in Oran is grounded in either full acceptance or denial of interpretation of faith. In The Last Man (1826), Mary Shelley wishes to tell the story "of the mournful passage of the death-cart" (p. 193). Jack London's The Scarlet Plague (1912) highlights ancestral fear of humans toward infectious disease. Alejandro Morales's The Rag Doll Plagues (1992) focuses on the theme of political othering and social parakiting during the outbreak of a horrific virus. Barbara Hambly's Fever Season (1998) tests the healing skills of a doctor and a voodoo alike as the city is overshadowed by the deadly cholera epidemic. These novels seek to give faithful account of the plague from imaginative, historical and fictional perspectives whereas the present paper aims to investigate the plague from a deterministic perspective.

Epidemic narratives have been studied intensively from different perspectives. Patrick Reilly (2015) and Jennifer Cooke (2009) study Defoe's Journal and Camus's The Plague presenting disease and destiny in plague literature, redefining destiny in the texts lending them meaning in the form of a metaphor (Reilly, p. 10) and exploring how both works intervene in history through fictions (p. 12). On representative plague texts, Ernest B. Gilman (2009) also points out that the memory of the past plagues has not gone and still has the power to wound the present (p. 5). Similarly, Hélène Dachez considers the plague in Defoe's Journal an unfashionable disease which causes damage inflected on the victims compared to $18^{\text {th }}$ century diseases (p. 127). In addition, Rebecca Totaro and Ernest Gilman (2010) analyse how people coped with plague pandemic in early modern England focusing on the content and form of plague writings (p. 18), while Michele Riva et al. (2014) state that The Scarlet Plague presents similar concerns of today and behavioural responses to a pandemic... (pp. 1754-56). Catherine Belling (2009) discusses the trauma of the 1918 flu in selected works dealing with this epidemic. In Porter's Pale Horse, Pale Rider, Laurel Bollinger (2013) and David A. Davis (2011) present an informative account of this epidemic affirming that the novel "illustrates the varieties of traumatic experience-personal trauma, cultural trauma, historical trauma, and aesthetic trauma" (Davis, p. 56), and "offers sustained examination of the pandemic, through a semi-autobiographical account of Porter's own neardeath encounter with the disease" (Bollinger, p. 366).

A review of the literature on epidemic fiction shows it has been usually studied from a wide perspective that tries to account for the human experience in its totality. The focus has been always on ancient and $20^{\text {th }}$ century novels. The present study uses a more specific perspective, a deterministic/freewill view, applied on recent fiction by contemporary writers. A deterministic view suggests that the human condition is a result of the connections between people and their environment or super powers that afflict them with troubles and disasters beyond their reach presenting the human characters as overwhelmed by accidental circumstances rather than by free will. An existentialist view, on the other hand, views the human being as a determiner of their own fate. When the whole existence is under threat, the human pursuit of identity and meaning becomes more meaningful (Flynn, p. 8). The selected novels discuss epidemics from different historical periods: medieval, early, and late 2oth century; they carry a contemporary touch not only in their publication, but also in their handling of the idea under discussion. 


\section{Ebola' 76}

Lewis Nawa in Ebola ' 76 (2012) is fated to visit Kinshasa and travels back contracting Ebola. Desires and past experiences have driven him to choose this path. With no signs of infection or the least expectation of the looming virus, he travels back to Nzara. It is not Lewis who freely chooses to be a victim as Elsir recounts his helplessness and his state of indeterminism: "As Lewis entered, Ebola was all around. It hovered inches from him, anticipating its moment to pounce" (p. 7). His fate to be there has caused a tremendous loss to his nation afterwards.

These powers and natural sorrows are beyond human control as Ebola destructs the human plans as seen through Tina, Lewis's wife, who plans for their 'renewed intimacy' to have a baby. Ebola has its own schemes to end her dreams and its master plan is inevitably beyond her reach. As it does on his wife's dreams, determinism seems also to operate well on Lewis's second life after recovering from the epidemic as the first victim to survive startling the doctors and nurses who had lost hope in his recovery. Whether Ebola has a peculiar habit of sparing its victims, as Elsir puts it (p. 7o), or any other factor, humans appear to have no freewill directing their own course of life.

People's reaction to Ebola has differed considerably. Positive attitude in quest for survival presented through the poor and the middle class who are mutually concerned about their safety and survival demonstrates resilience against the spread of Ebola and mass deaths and their commitment towards each other despite the devastating situation: "Ebola continued to kill and wreak havoc, depriving wives of their husbands, neighbours of their neighbours, children of their parents and lovers of their loved ones" (p. 103). Besides, hope and acceptance of the people and their resignation to their fate is well depicted to confront the grim facts of burial sites and their agony. Their sense of forgiveness is also apparent when nobody blames Lewis for what has happened because they feel it is beyond their human control as stated by Elsir: "The deadly Ebola was not entirely sure what it found so intriguing about Lewis Nawa, ... and it had resolved to enter his bloodstream and migrate to another land" (p. 8).

Comic sense as shown through the factory workers who react with funny remarks on the spread of the epidemic to distract themselves from thinking about it stating that such a mysterious illness only affects monkey-like people. They bring banana peels from a worker's office to prove their whisper and begin to search if they have tails (p. 66). In addition, degeneration of moral sense and human values have been tested through James Riyyak, a factory owner, who turns everything to his own advantage and refuses to offer help to others. His capitalist motives determines him as "fearless in the face of Ebola, viewing it as just as one more affliction ... to overcome in the course of his life (p. 79), and he acts freely for he "was confident the epidemic would die down and life would improve" (p. 125). Wealthy people's values and their silly worries about the education of their children, clot of their veins and cholesterol levels due to quarantine have been satirized as well.

\section{This Time of Dying}

Set behind the backdrop of Spanish flu of 1918, Reina James's This Time of Dying (2006) conveys the day-to-day effect of the epidemic influenza on a small London community. At the very onset, the undertaker, Henry, tries to alert the authorities to a letter he has found written by a dying doctor who warns: "I repeat: a plague is now among us which may well leave the earth to the animals" (p. 6). Social structure breaks down as the death tolls mount. Authorities seem to ignore Dr Wey's premonition of disaster that "There are no circumstances, save peace and universal quarantine, that can afford even the slightest hope" (p. 12). The novel mirrors the breakdown of 
eco-system as ordinary souls grapple with the practicalities of the day. Men were dying out of all proportion: "the streets were quiet, except for the increasing number of hearses" (p. 194); those whom death devoured were "unusually young" (p. 63). With the death of two teachers and two students because of influenza, the school finally gets closed as all preventive means fail. Once Dr. Tite falls ill, system of signing the death certificates even collapses. With each day passing, the letter continues to pile up for his signature on death certificate. His wife Charlotte finally opens the certificate lists in front of her ailing husband with a plea to sign them. He finally arrives at a diagnosis and signs the certificate after carefully listening to their cases (p. 232).

For fear of the accumulation of bodies, the undertaker comes up with the idea of mass cremation since it takes no more than an hour to reduce a man to ashes; with continuous burning one might be able to deal with twenty or more bodies in a day. Even though cremation had been in practice in England since 1885, he had been unable to persuade a single customer because old ideas stood in the way as "people saw it as a godless end with nothing left of you to be collected at the Judgement" (p. 185). Reverend Lucerne initially takes the orthodox views about pandemics that "God, in his providence, might well be offering man an antidote to the cruelties of war." But in his private communion he was disagreeing with God as he observes the paradox: punishment, deplorably, was not reserved for the guilty but the good "were paying heavily for the bad" (p. 130). As the situation worsens, Reverend Father's epiphenomenalist views are jolted as he engages himself in spiritual monologues:

Was God absenting himself from this pestilence? ... Having always held to the view that faith could not be dependent on circumstance, he was shaken to find that his own faith was tottering ... Prayer was proving to be no more successful than quack remedies and charms. (p. 243)

\section{The Plague Charmer}

The Plague Charmer (2016) by Karen Maitland tells the story of the plague in a sea-shore community thirteen years after the Great Pestilence of London in 1348. In another wave that hit England in 1361, people still have memories of their sufferings and lost loved ones. When she gets the news, the caring mother Sara holds her kids tightly in her arms and recounts how she still has nightmares of the "bloated corpse" of her mother and awakes "with the sickly stench of her death in [her] nostrils" (p. 6o). However, the plague news brings to them something more threatening. Janiveer, the strange woman whom they have rescued from the sea, offers help for a price that is neither gold nor silver. "A human life," she says, "That is my price ... just one, to save you all" (p. 69). It is a fight to preserve human existence at the price of human life. Communities may be accustomed to see people who are willing to give their lives to save others, but it is difficult for the community to select an individual to be a scapegoat for them. It is a freewill decision-making that tests human resilience and hope for survival. However, the horror that later grasps their very existence makes this completely rejected offer at the beginning a plausible one: "What Janiveer asked then," concludes Sara, "does not seem so great a price now" (p. 161). To save her kids and the others, she decides to sacrifice herself.

The way the contagion reaches the village displays convergent worldviews that are particular to the medieval time-sitting of the novel and universal for the human condition in general. The sea throws out two dead babies tied together. The villagers neither throw them back, as the tradition says, nor summon the priest; instead, they decide to prepare them unofficially for a decent burial. Once in Sara's cottage, they discover they have the contagion. Matilda, the old woman, thinks it has been brought to the village by the witchcraft of Janiveer blaming the villagers at the same time for their sins and refusal to be obedient to the church's rules. Parallel to 
Matilda's completely religiously deterministic worldview, the villagers hold a similar deterministic worldview that is a mixture of naturalistic and religious determinism. It is the sea that has its rule and inflicts its actions on human beings. When Luke, Sara's son, brings a box from the sea and tries to open it, his mother and the others ask him not to do. At the time Luke blames her for her decision to bring the babies into their cottage, she blames him for causing the sea to seek revenge. However, later when her husband, Elis, gets the disease, she thinks that God is punishing her because she left her dying mother when she could not stand the sufferings. A third deterministic worldview is the end of life worldview of the Chosen Ones: an apocalyptic cult that consider signs like plagues an end of the world when God would destroy the sinful who refused to accept the truth of their message.

At such a troubled time, people show the best and worst of human behaviour. Out of fear, people put their safety first neglecting others; fear is "easily caught than the pestilence" (p. 219). Sara and her family find themselves trapped in their cottage by the villagers as it is the cottage that had the contagion from the babies. Supplies of food, water and wood are first provided then stopped and the trapped people are suffering from hunger and thirst. The villagers think that by quarantining the plagued family and concealing the matter from the authorities, they have the issue under their control. However, they can do nothing to stop it. Almost all the young male members get the pestilence and die leaving women and older people wondering about the causes of the plague and the means to face it in a pre-modern-medicine age.

\section{Conclusion}

An analysis of the selected novels reveals the questions that usually underlay much of the traumatic events portrayed in their narrative pertaining to human struggle to live throughout some outside life-ending forces and raises issues of destiny and freewill leading to more questions about human relations, values and believes. The novels, though feature historical events, predict the contemporary society with their resonance of apocalyptic images and preventive measures. They also manifest ontological shifts as the orthodox worldviews are jolted. Finally, they prove that fictional and personal narratives are not less important than historical records on health in an endless quest for existence.

\section{Funding Disclosure/Acknowledgement}

The authors extend their thanks and sincere gratitude to the Scientific Research Deanship at the University of Bisha, Saudi Arabia, for funding this research as part of its COVID-19 Initiative: Research\# (UB-COVID-30-1441).

\section{References}

Beidler, P. G. (1982). The Plague and Chaucer's Pardoner. The Chaucer Review, 16(3), 257-269. doi:www.jstor.org/stable/25093795. Accessed 22 June 2020.

Boccaccio, G. (1972). The Decameron. (G. H. McWilliam, Trans.) Harmondsworth: Penguin.

Bollinger, L. (2013). Trauma, Influenza, and Revelation in Katherine Anne Porter's "Pale Horse, Pale Rider". Papers on Language \& Literature, 49(4), 364-389.

Cooke, J. (2009). Legacies of Plague in Literature, Theory and Film. London: Palgrave Macmillan.

Dachez, H. (2016). Fashioning Unfashionable Plague: Daniel Defoe's Journal of the Plague Year (1722). In L. W. Dickson, \& A. Ingram, Disease and Death in Eighteenth-Century Literature and Culture: Fashioning the Unfashionable (pp. 127-144). Lancaster: Palgrave Macmillan. doi:10.1057/978-1-13759718-2 
Davis, D. A. (2011). The Forgotten Apocalypse: Katherine Anne Porter's 'Pale Horse, Pale Rider', Traumatic Memory, and the Influenza Pandemic of 1918. The Southern Literary Journal, 43(2), 55-74. doi:10.1353/slj.2011.0007.

Elsir, A. T. (2015). Ebola '76. (C. B. Danby, Trans.) London: Darf Publishers (SCRIBD). Retrieved from https://www.scribd.com/read/375961244/Ebola-76\#

Flynn, T. (2006). Existentialism: A Very Short Introduction. Oxford: Oxford University Press.

Gilman, E. B. (2009). Plague writing in early modern England. University of Chicago Press. James, R. ( 2006). This Time of Dying. London, United Kingdom: Portobello Books Ltd.

Keys, T. E. (1944). The Plague in Literature. Bull Med Libr Assoc, 32(1), 35-56.

Maitland , K. (2016). The Plague Charmer. London: Headline Review.

Newman, K. L. (2012). Shutt Up: Bubonic Plague and Quarantine in Early Modern England. Journal of Social History, 45(3), 809-834. Retrieved from www.jstor.org/stable/41678910

Reilly, P. (2015). Bills of Mortality: Disease and Destiny in Plague Literature from Early Modern to Postmodern Times. New York: Peter Lang Publishing, Inc.

Riva, M. A., Benedetti, M., \& Cesana, G. (2014). Pandemic Fear and literature: Observations from Jack London's The Scarlet Plague. Emerging infectious diseases, 20(10), 1753-7. doi:10.3201/eid2010.130278 Shelley, M. (2012). The Last Man. : Courier Corporation.

Steel, D. (1981, June ). Plague Writing: From Boccaccio to Camus. ournal of European Studies, 11(42), 88-110. doi:10.1177/004724418101104202

Totaro, R., \& Gilman, E. B. (2010). Representing the Plague in Early Modern England. Routledge.

${ }^{1}$ Dr. Abdel-Fattah M. Adel is a PhD holder in English Language and Literature: Literary Criticism and Theory. He teaches courses in literature and literary criticism at the University of Bisha, Saudi Arabia. His main research interest is literary and critical theories, contemporary English literature, and theories of reading.

${ }^{2}$ Dr. Mashhoor Abdu Mohammad Al-Moghales is an Associate Professor of English Literature at Taiz University, Yemen. Currently, he teaches courses in literature and language at the University of Bisha, Saudi Arabia. His main research interest is English literature, comparative literature, and drama.

${ }^{3}$ Dr. Suhail Ahmad is an Assistant Professor in the Department of English, University of Bisha, Saudi Arabia teaching both language and literature. Formerly, he taught at Aligarh Muslim University, India. His main research thrust is modern English literature, postcolonial theory, and comparative literature. 